\title{
Primary lymphoma of the upper small intestine
}

KHOSROW NASR, PARVIZ HAGHIGHI, KIUMARS BAKHSHANDEH, AND MANSOUR HAGHSHENAS

From the Pahlavi University School of Medicine, Shiraz, Iran

SUMMARY Seven patients with primary lymphoma involving the upper small intestine and presenting with diarrhoea, non-specific abdominal pain, and clubbing are reported. The disease appears to be more prevalent in young women, and clinical and radiological findings can provide an excellent preliminary diagnosis which is usually confirmed by peroral biopsy of the small intestine. This type of lymphoma is found to be clinically distinguishable both from the primary intestinal lymphomas reported from western countries and also from gastrointestinal involvement as part of a more systemic disease. It appears to be prevalent in the Middle East, and because of clear clinical, radiological, and histological features, it can be singled out from other primary intestinal lymphomas and considered as a distinct clinical entity.

Though lymphomas frequently involve the gastrointestinal tract as part of a more generalized disease (Ehrlich, Stadler, Geller, and Sherlock, 1968), intestinal involvement as the sole manifestation of lymphoma has rarely been reported (Eidelman, Parkins, and Rubin, 1966; Jinich, Rojas, Webb, and Kelsey, 1968; Kent, 1964; Marcuse and Stout, 1950; Ramot, Shahin, and Bubis, 1965; Sacks and Seijffers, 1968; Sleisenger, Almy, and Barr, 1953; Allen, Donaldson, Sniffen, and Goodale, 1954). Furthermore, most of the reports dealing with upper small intestine lymphomas have been from Israel, suggesting the possible significance of geographical or ethnic factors (Eidelman et al, 1966; Ramot et al, 1965; Sacks and Seijffers, 1968). Our group of patients are Moslems from southern Iran and we present them to emphasize the apparent geographical importance of what is becoming a clear clinical entity.

\section{Patients}

Recently one of us (K.N.) was asked to review a necropsy and see six other patients who are Received for publication 29 October 1969. the subject of this report. All the patients were seen at the Saadi and Nemazi Hospitals, the main teaching services of the Pahlavi University. One case is presented fully while the significant clinical information on all seven patients is included in Table $\mathrm{I}$.

Case 1 (S.M.S.) is a 19-year-old Moslem youth from a village in southern Iran who, two years before his admission, had bloody diarrhoea and fever which appeared to have responded to medications given to him by a local physician unknown to us. One month after the symptoms had subsided, he once again had diarrhoea (six to 10 motions a day) which he described as watery and foul but not containing blood. Diarrhoea was accompanied by abdominal distension and a dull, continuous, non-radiating periumbilical pain. Despite various drugs prescribed by several physicians, his symptoms continued and one year before admission he underwent a laparotomy at a local hospital. The operative note on that admission describes large mesenteric nodes but no other abnormality. A mesenteric node biopsy was interpreted as showing reticulum cell hyperplasia, although we were unable to review this tissue.

After being discharged his symptoms continued and he was finally referred to the Pahlavi 


\begin{tabular}{|c|c|c|c|c|c|c|c|c|c|c|c|c|}
\hline \multirow[t]{2}{*}{ Case } & \multirow{2}{*}{$\begin{array}{l}\text { Age }(y r) \\
\text { and Sex }\end{array}$} & \multirow{2}{*}{$\begin{array}{l}\text { Presenting } \\
\text { Complaints }\end{array}$} & \multirow[t]{2}{*}{ Clubbing } & \multirow{2}{*}{$\begin{array}{l}\text { Extent of } \\
\text { Intestinal } \\
\text { Disease }\end{array}$} & \multirow{2}{*}{$\begin{array}{l}\text { Extra- } \\
\text { intestinal } \\
\text { Involvement }\end{array}$} & \multicolumn{3}{|c|}{ Malabsorption $^{2}$} & \multicolumn{2}{|l|}{ Stool ${ }^{3}$} & \multirow[t]{2}{*}{ Complications } & \multirow[t]{2}{*}{ Follow up } \\
\hline & & & & & & $\begin{array}{l}\text { Xylose } \\
\text { Test }(g)\end{array}$ & $\begin{array}{l}\text { Schilling } \\
\text { Test }(\%)\end{array}$ & $\begin{array}{c}\text { Stool } \\
\text { Fat }\end{array}$ & Blood & Parasites & & \\
\hline 1 (S.M.S.) & $19 \mathrm{M}$ & $\begin{array}{l}\text { Diarrhoea, } \\
\text { abdominal } \\
\text { pain for } \\
2 \text { years }\end{array}$ & No & Jejunum & None & $3 \cdot 2$ & $1 \cdot 7$ & None & Positive & $\begin{array}{l}\text { Giardia, } \\
\text { E. histolytica }\end{array}$ & None & $\begin{array}{l}27 \text { months } \\
\text { alive }\end{array}$ \\
\hline 2 (M.Z.) & $55 \mathrm{~F}$ & $\begin{array}{l}\text { Abdominal } \\
\text { pain for } \\
5 \text { years }\end{array}$ & No & Jejunum & None & - & - & 一 & Positive & None & Perforation & $\begin{array}{l}5 \text { years, } \\
\text { necropsy }\end{array}$ \\
\hline 3 (M.J.) & $35 \mathrm{~F}$ & $\begin{array}{l}\text { Abdominal } \\
\text { pain for } \\
3 \text { years }\end{array}$ & $\begin{array}{l}\text { Not } \\
\text { known }\end{array}$ & $\begin{array}{l}\text { Duodenum } \\
\text { and jejunum }\end{array}$ & $\begin{array}{l}\text { Ovary } \\
\text { (microscopic) }\end{array}$ & - & - & - & Positive & Giardia & None & $\begin{array}{l}3 \text { years, } \\
\text { necropsy }\end{array}$ \\
\hline 4 (R.G.) & $22 \mathrm{M}$ & $\begin{array}{l}\text { Diarrhoea, } \\
\text { abdominal } \\
\text { pain for } \\
4 \text { months }\end{array}$ & Yes & $\begin{array}{l}\text { Duodenum, } \\
\text { jejunum and } \\
\text { possibly } \\
\text { ileum }\end{array}$ & None & - & - & - & Negative & None & None & $\begin{array}{l}15 \text { months, } \\
\text { alive }\end{array}$ \\
\hline 5 (E.A.) & $30 \mathrm{~F}$ & $\begin{array}{l}\text { Diarrhoea } \\
\text { for } 3 \text { years }\end{array}$ & Yes & $\begin{array}{l}\text { Duodenum } \\
\text { and jejunum }\end{array}$ & Omentum & 一 & 13 & None & Negative & None & None & $\begin{array}{l}3 \text { years, } \\
\text { dead }\end{array}$ \\
\hline 6 (P.H.) & $19 \mathrm{~F}$ & $\begin{array}{l}\text { Diarrhoea } \\
\text { for } 8 \text { months }\end{array}$ & No & $\begin{array}{l}\text { Duodenum } \\
\text { and jejunum }\end{array}$ & $\begin{array}{l}\text { Spleno- } \\
\text { megaly, not } \\
\text { diagnosed } \\
\text { as lymphoma }\end{array}$ & - & - & 一 & Positive & Giardia & None & $\begin{array}{l}8 \text { months, } \\
\text { alive }\end{array}$ \\
\hline 7 (S.K.) & $18 \mathrm{~F}$ & $\begin{array}{l}\text { Diarrhoea, } \\
\text { abdominal } \\
\text { pain for } \\
3 \text { years }\end{array}$ & No & $\begin{array}{l}\text { Duodenum } \\
\text { and jejunum }\end{array}$ & None & - & 0.5 & - & Positive & None & None & $\begin{array}{l}3 \text { years, } \\
\text { alive }\end{array}$ \\
\hline
\end{tabular}

Table I The main clinical features of the seven patients with primary upper small-intestinal lymphoma

${ }^{1}$ On the basis of radiology, peroral intestinal biopsy, laparotomy, or necropsy findings.

${ }^{2}$ Xylose-five-hour urinary excretion after $25 \mathrm{~g}$ oral intake (normal $>5 \mathrm{~g}$ ). Schilling-with intrinsic factor (normal $>7 \%$ excretion). Stool fat estimation based on Sudan stain smears.

${ }^{3}$ Stool culture-no pathogenic organisms.

University Medical Centre (Saadi Hospital). Though he had not weighed himself, he believed that he had noticeably lost weight in the last two years.

Physical examination showed an emaciated young man with slight abdominal distension and mild tenderness in the epigastric and periumbilical region. There were no palpable nodes, hepatosplenomegaly, or clubbing.

Laboratory findings showed that the haemoglobin was $5.5 \mathrm{~g} \%$, haematocrit $17 \%$, reticulocytes $3.2 \%$; the white blood count was 17,440 $7,900 \mathrm{cmm}$ with a normal differential; FBS $70 \mathrm{mg} \%$, blood urea nitrogen was $8 \mathrm{mg} \%$, urine was normal; total bilirubin $0.5 \mathrm{mg} \%$ (direct $0.2 \mathrm{mg} \%$ ), alkaline phosphatase $17 \cdot 1$ Bodansky units, SGOT 30, SGPT 40; albumin $2 \mathrm{~g} \%$, globulin $3.2 \mathrm{~g} \%$. The stools were positive for occult blood but negative for fat, and a smear showed Giardia lamblia and on culture grew Escherichia coli. Sigmoidoscopy showed a mild proctitis with Entamoeba histolytica on biopsy. A Schilling test with intrinsic factor gave $1.7 \%$ excretion in 24 hours (normal $7.5 \mathrm{~g}$ ); xylose absorption tests showed $3 \cdot 2 \mathrm{~g}$ excreted in the urine in five hours after $25 \mathrm{~g}$ intake.

Radiographs showed a normal oesophagus, stomach, and duodenum, a diffuse abnormality of the upper jejunum (Fig. 1), and a segmental narrowing of the descending colon with an otherwise normal mucosal pattern. Peroral small intestinal biopsy (Ca:ey capsule) showed reticulum-cell sarcoma (Figs. 2 and 3 ).

While in the hospital the patient was initially treated for giardiasis and subsequently for amoebiasis with no change in the symptoms. He was then surgically explored. At laparotomy, there was thickening of the upper jejunum with enlargement of the mesenteric nodes but the colon appeared normal. Jejunal and mesenteric node biopsies showed reticulum-cell sarcoma

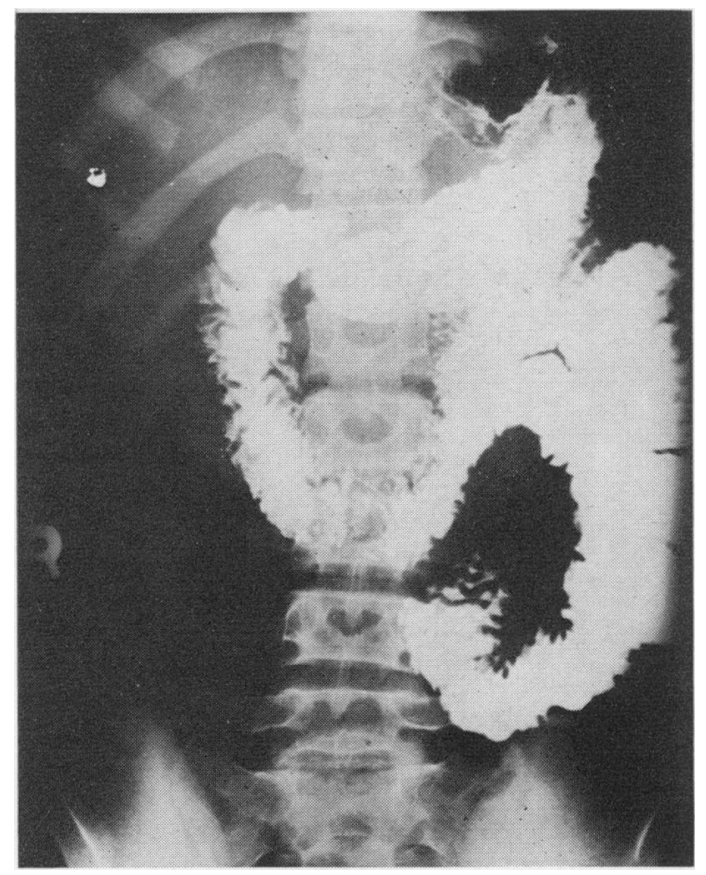

Fig. 1 A barium study of the upper gastrointestinal tract showing a diffuse abnormality of the duodenum and proximal jejunum. 


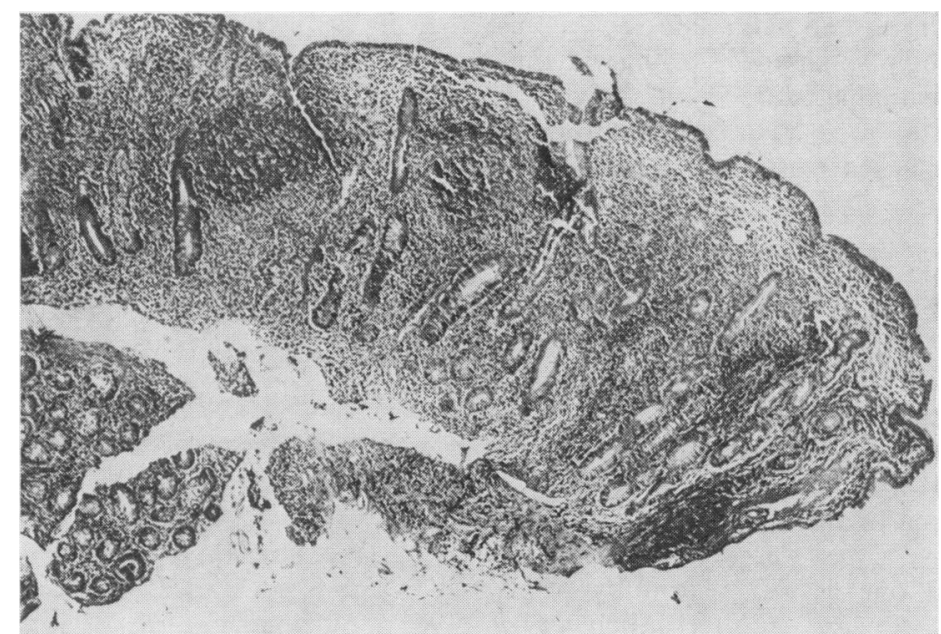

Fig. 2

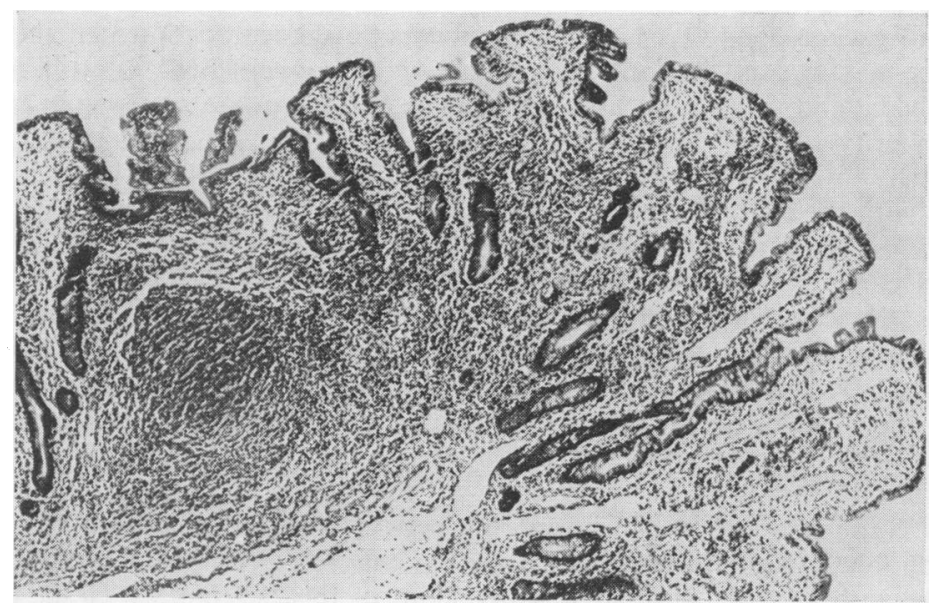

Fig. 3

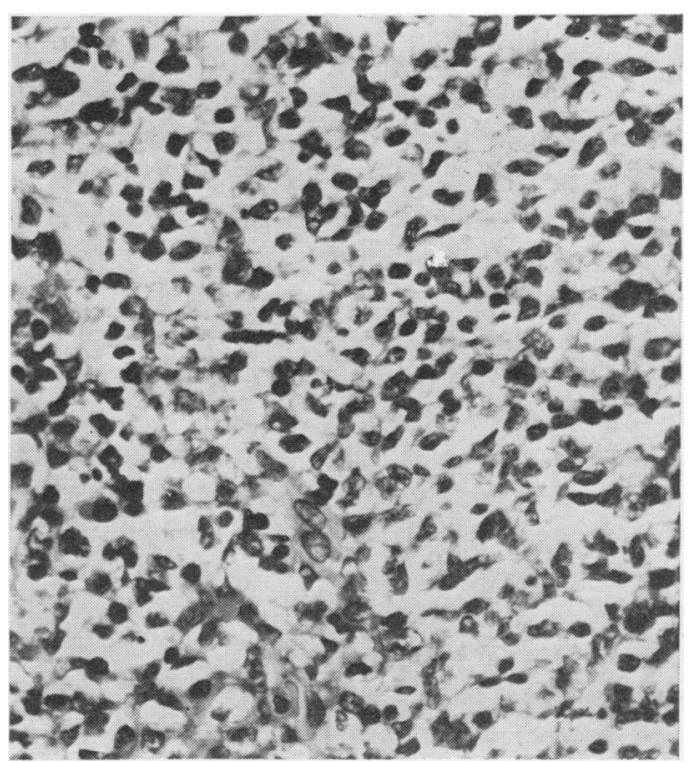

Fig. 4

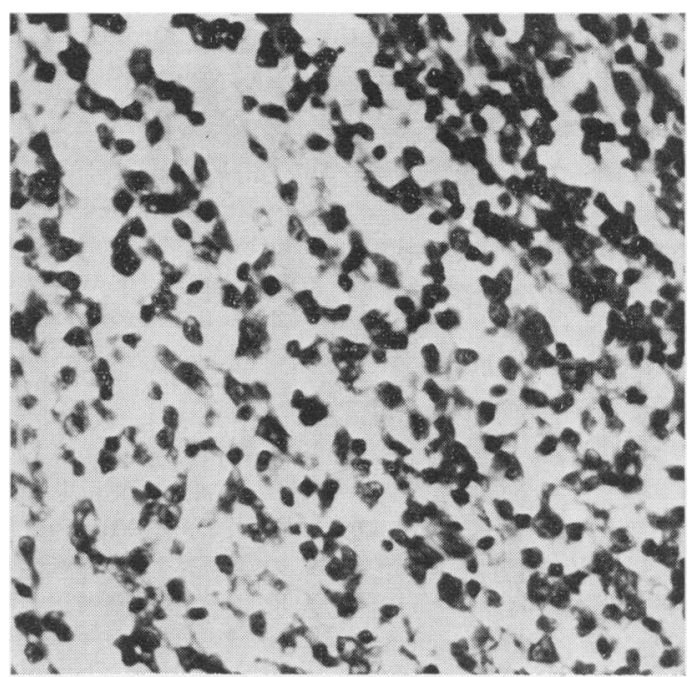

Fig. 5

showing severe flattening of villi and marked hypercellularity of the lamina propria with a focal follicular pattern.

Fig. 3 Higher magnification of the lamina propria from Fig. 2 showing the pleomorphism of the cellular infiltrate, consisting of neoplastic reticulum cells and lymphocytes.

Fig. 4 Small-intestinal biopsy obtained at laparotomy showing a definite distortion of the villous architecture and a markedly cellular lamina propria with a focal follicular pattern. Compare with peroral intestinal biopsy of Figure 2.

Fig. 5 Higher magnification of the cellular infiltrate of Figure 4. The cell population consists of neoplastic reticulum cells and lymphocytes.

Fig. 6 Mesenteric node obtained at laparotomy and on low-power view showing complete obliteration of the nodal architecture by a diffuse infiltrate of neoplastic reticulum cells.

Figs. 2 to 6 Haematoxylin and eosin, $\times 31$.

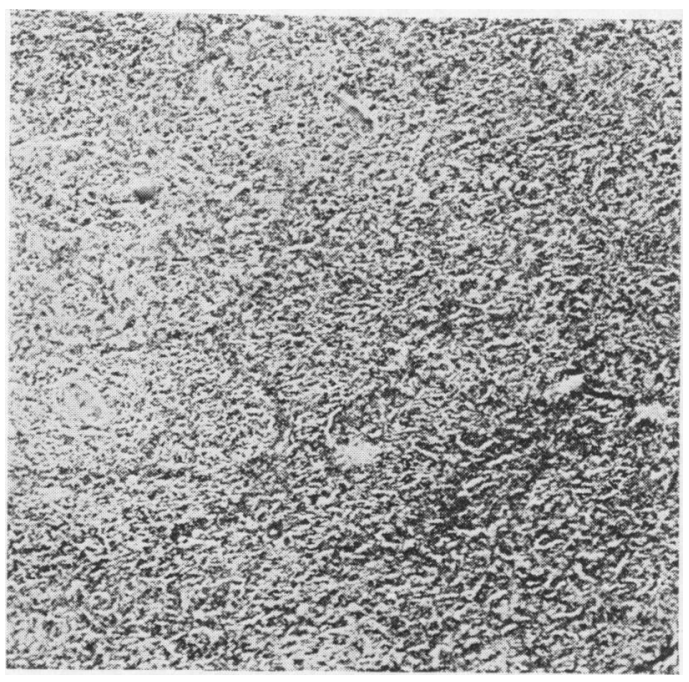

Fig. 6

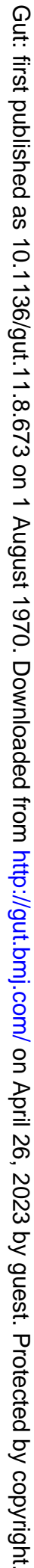


(Figs. 4, 5, and 6). Subsequently, the patient was started on corticosteroids, cyclophosphamide (Cytoxan), and, when it became available, wide portal abdominal irradiation (5,100 rads). He seemed to be doing well three months after treatment.

\section{Pathological Findings}

Of our seven cases, five had peroral smallintestinal biopsies (Carey capsule), two taken from the duodenum and three from the jejunum. Using the classification of lymphoma of Jackson and Parker (1944), four of the five cases were diagnosed as lymphosarcoma and one as reticulum-cell sarcoma (Table II).

Histological features noted on the peroral biopsy specimens included moderate to severe destruction of the villous architecture with flattening of villi in all cases. In all except one case, the relative number of crypts to villi was moderately to markedly diminished, and all biopsies showed marked hypercellularity of the lamina propria. This hypercellularity included cellular pleomorphism in two cases with the cells consisting of lymphocytes, plasmacytes, and reticulum cells, being the plasma cells close to the surface epithelium. In three cases the cellular infiltrate was fairly uniform, consisting of neoplastic lymphocytes occasionally intermixed with reticulum cells. Reed-Sternberg cells were not identified in any of the cellular infiltrates. In two cases the lymphosarcoma had a partially follicular pattern, the germinal centres containing a one-cell type of population of lymphoblasts with no phagocytosis. In two cases where the muscularis propria was present it was invaded by neoplastic cells. Marked dilatation of the lymphatics of the lamina propria was observed in one case.

In the five cases biopsied, the histological features of the specimen were quite distinctive for a lymphomatous process and there could be no confusion with other bowel diseases such as coeliac disease or tropical sprue. On the other hand, solely by examining the peroral intestinal

\begin{tabular}{|c|c|c|c|c|}
\hline \multirow[t]{2}{*}{ Case } & \multirow{2}{*}{$\begin{array}{l}\text { Peroral } \\
\text { Small-intestinal } \\
\text { Biopsy }\end{array}$} & \multicolumn{2}{|l|}{ Laparotomy } & \multirow[t]{2}{*}{ Necropsy } \\
\hline & & $\begin{array}{l}\text { Small-intestinal } \\
\text { Biopsy }\end{array}$ & $\begin{array}{l}\text { Mesenteric } \\
\text { Node Biopsy }\end{array}$ & \\
\hline 1 & $\begin{array}{l}\text { Reticulum-cell } \\
\text { sarcoma }\end{array}$ & $\begin{array}{l}\text { Reticulum-cell } \\
\text { sarcoma }\end{array}$ & $\begin{array}{l}\text { Reticulum-cell } \\
\text { sarcoma }\end{array}$ & - \\
\hline 2 & - & $\begin{array}{l}\text { Reticulum-cell } \\
\text { sarcoma }\end{array}$ & $\begin{array}{l}\text { Not removed } \\
\text { surgically }\end{array}$ & $\begin{array}{l}\text { No lymphoma } \\
\text { found }\end{array}$ \\
\hline 3 & - & - & Lymphosarcoma & $\begin{array}{l}\text { Lympho- } \\
\text { sarcoma }\end{array}$ \\
\hline 4 & Lymphosarcoma & - & Lymphosarcoma & - \\
\hline 5 & Lymphosarcoma & - & Lymphosarcoma & - \\
\hline 6 & Lymphosarcoma & - & Lymphosarcoma & - \\
\hline 7 & Lymphosarcoma & 二 & Lymphosarcoma & - \\
\hline
\end{tabular}

Table II Pathological diagnoses in seven patients with primary lymphoma of the upper small intestine biopsy, a histological distinction between a primary lymphoma of the gastrointestinal tract and a secondary lymphoma involving the gut was not possible.

The diagnosis from the peroral biopsy was confirmed in all five cases by laparotomy and surgical biopsy from the small intestine (one case) or mesenteric node biopsy (all five cases). In all, two of the seven patients had reticulum-cell sarcoma and the remaining five lymphosarcoma (Table II).

\section{Discussion}

Lymphoma involving the intestines may be primary or part of a more generalized disease (Ehrlich et al, 1968; Eidelman et al, 1966; Jinich et al, 1968; Kent, 1964; Marcuse and Stout, 1950; Ramot et al, 1965; Sacks and Seijffers, 1968; Sleisenger et al, 1953; Allen et al, 1954). All our patients have been documented as having lymphoma of the upper small intestine with little or no evidence of a more systemic involvement. They have all been Moslems from southern Iran. Twenty-threesimilar cases have been recently reported from several centres in Israel (Eidelman et al, 1966; Ramot et al, 1965; Sacks and Seiffers, 1968). Reference to this tumour from western countries has been infrequent (Marcuse and Stout, 1950; Sleisenger et al, 1953). Thus, on the basis of the reported cases, there is little doubt that this type of lymphoma is more significantly frequent in the Middle East.

Our group was predominantly female (five out of seven) and between the ages of 18 and 55 . There were four patients under 25 years of age compared with 17 out of the 23 from the Israeli group, emphasizing the occurrence of this disease at all ages with a prevalence in the young. This is in contrast to the age distribution pattern noted in western series, such as that by Sleisenger et al (1953) who reported and reviewed 15 patients who were all above 30 with an average age of 50.4 years. Similar observations have been made by others in series of primary intestinal lymphoma (Marcuse and Stout, 1950). Our patients were predominantly female while the Israeli group of 23 cases included 13 males. This is in sharp contrast to the ratio noted in western series where males outnumbered females by more than three to one (Marcuse and Stout, 1950; Sleisenger et al, 1953).

The main complaints of our group included diarrhoea (two patients), non-specific abdominal pains (two patients), or both (three patients). The duration of these symptoms extended from four months to five years. Examination of two patients showed no remarkable features except for definite clubbing. This compares well with reports from Israel, and our findings regarding the frequency of clubbing are of interest and remain unexplained. 
The extent of intestinal involvement included the duodenum and upper jejunum (five cases) and jejunum alone (two cases). Six patients who underwent either a laparotomy or necropsy were found to have an involvement of a mesenteric node. Otherwise, one patient had microscopic involvement of the ovary, another had disease in the omentum, while the third had a splenomegaly which on laparotomy did not appear lymphomatous. Since splenomegaly of unknown aetiology is frequently encountered in our area, one cannot assume the splenomegaly to be definitively related to the lymphoma. Despite this occasional extraintestinal involvement, the presenting clinical picture has always been one suggestive of intestinal disease.

Radiological evaluation has demonstrated disease in the upper small intestine characterized by segmental dilatation and narrowing, a thickened bowel wall, a coarse and abnormal mucosal pattern, delayed transit time and posttransit puddling of barium. Considering our radiological findings and the rarity of other upper small intestine diseases in our area, we consider this clinical and radiological presentation to be highly suggestive of primary upper small intestine lymphoma. Only one patient on a subsequent evaluation was found to have radiological changes suggestive of small intestine disease extending to the ileum. Otherwise, none of our patients had apparent disease in any other segment of the gastrointestinal tract. This contrasts sharply with both primary small intestine lymphoma, as reported from western countries, as well as the secondary gastrointestinal lymphomas. In the former, the disease appears more prevalent in the ileum, and this is to be expected considering the prevalence of lymphoid tissue in that area (Marcuse and Stout, 1950). On the other hand, in cases with secondary gastrointestinal lymphomas, there is segmental, and at times involvement of the entire alimentary tract with a greater prevalence in the stomach (Ehrlich et al, 1968).

Though our patients presented with diarrhoea, their stool characteristics were not suggestive of steatorrhoea. Only two patients had smear examinations of the stools for fat which were negative. Unfortunately, we were unable to carry out more quantitative fat studies or a more extensive one of malabsorption. Nevertheless, one patient did have a xylose absorption test and it was abnormally low, while three others had radioactive vitamin $B_{12}$ absorption tests, and of these two had an abnormally low absorption in the presence of intrinsic factor. These two patients did not have any ileal involvement and unfortunately were too ill to permit evaluation in terms of antibiotic responsiveness. In contrast to these limited studies, other reports have clearly documented malabsorption, especially with reference to fat (Eidelman et al, 1966; Jinich et al, 1968; Kent, 1964; Ramot et al, 1965; Sacks and Seijffers, 1968; Sleisenger et al, 1953). Whether steatorrhoea is due to the involvement of the absorptive surface is not clear, but in a few of the patients reported the steatorrhoea improved after antibiotic therapy, suggesting the possibility of bacterial overgrowth, perhaps related to stasis, leading to unconjugation of bile salts and a decrease in the critical micellar concentration (Ramot et al, 1965).

Pathologically, the specimen obtained by peroral biopsy of the small intestine was adequate for making the diagnosis of lymphoma in every patient biopsied. The main histological features on peroral biopsy included villous atrophy and hypercellularity. The latter was a neoplastic infiltration consisting of either a monotonous lymphoid cellularity or a mixture including large reticulum cells and larger lymphocytes. A decrease in crypts was not uniformly observed. Similar observations have been reported by others (Eidelman et al, 1966).

Of the seven patients, two had reticulum-cell sarcoma and five lymphosarcoma. This contrasts with nine patients with reticulum-cell sarcoma, three with lymphosarcoma, and one with Hodgkin's disease as reported from one Israeli centre (Ramot et al, 1965). This diagnostic discrepancy is unexplained and may be partly due to differences in terminology.

Our period of therapy and follow up has been too brief to permit any meaningful conclusions. Our present approach includes diagnosing intestinal lymphoma on the basis of clinical, radiological, and peroral biopsy changes. If characteristic intestinal alterations are not seen on the biopsy specimen (and this may require several biopsies) the patient undergoes a laparotomy for a definitive diagnosis. Once the diagnosis has been made, the extent of the disease is determined on the basis of findings on clinical examination, chest radiographs and, when possible, lymphangiography. Considering the wide portals used in radiating the abdomen, we do not feel that the extra risk of a laparotomy is always warranted. So far, we have never had a case where preoperative determination of the extent of disease permitted of resection. On the other hand, the patient M.Z. was admitted with perforation and had an apparently curative resection. Thus, laparotomy is performed for diagnosis if this cannot be made by peroral biopsy of the small intestine or for definitive surgical therapy if this appears possible on the basis of radiological evaluation. With the possibility of a curative resection excluded, the patient is then treated with corticosteroids and abdominal radiation. Steroid therapy is initiated with $60 \mathrm{mg}$ of prednisone daily and eventually the patient is maintained on 20 to $30 \mathrm{mg}$ per day. On the basis of the Israeli reports, there is no clear evidence that corticosteroids lead to anything but subjective improvement (Eidelman et al, 1966; Ramot et al, 1965). Initially, the patient also receives abdominal irradiation (5,000 rads). 
Subsequently, in three to six months, the patient is re-evaluated and in the presence of any evidence of lymphoma, added therapy with cyclophosphamide (Cytoxan) is initiated $(5 \mathrm{mg} / \mathrm{kg}$ body weight intravenously for two weeks, then orally as long as it is tolerated and there is a response). With no cures reported in the literature, we are uncertain about the benefits of our therapeutic regimen.

Our patients have lived for up to five years from the onset of clinical symptoms. So far, three have died, two three years and one five years after the onset of their complaints. One patient presented with jejunal perforation and limited intestinal involvement (M.Z.). She died postoperatively and had no evidence of disease at necropsy. Other reported complications include obstruction and intusussception (Eidelman et al, 1966; Ramot et al, 1965).

Nothing can be definitely concluded regarding the possible aetiological factors relating to primary upper small-intestinal lymphomas. Reports from Israel have emphasized the presence of this disease in the local inhabitants and not in Europeans who had emigrated (Eideliman et al, 1966; Ramot et al, 1965). Our group of patients have been Moslems from Iran. Both our findings and the paucity of similar reports from western countries stress the importance of the geographical distribution of this entity. Reports from other places are needed before any meaningful conclusion can be reached regarding its world-wide distribution and possible aetiological factors.

Of interest are reports from the west suggesting a higher incidence of lymphoma of the upper small intestine in those with longstanding coeliac disease (Austed, Cornes, Gough, McCarthy, and Read, 1967). No well defined case of gluten enteropathy or tropical sprue has, so far, been diagnosed in our area. But, it is possible that chronic low-grade nonsymptomatic intestinal injury may be present and perhaps related to parasites or a marginal low protein diet. Though our patients were primarily from a low-income bracket with a poor dietary history, two of them were from the lower middle class with a more adequate diet. And, although no information is available regarding a previous history of intestinal parasites, on admission four of the seven had Giardia lamblia, Entamoeba histolytica, or both. It is of particular interest that three of the seven had Giarda which is found in the upper small intestine. Whether primary lymphoma of the upper small intestine leads to a more frequent giardiasis and whether this may be due to alterations in the immunological milieu of the upper small intestine remains to be investigated.

In conclusion, primary lymphoma of the upper small intestine is a distinct entity, differing from the secondary gastrointestinal lymphomas as well as the primary small intestinal lymphomas reported from the west. Its geographical distribution, with the main reports coming from the Middle East, is of great interest and may contain a clue to its pathogenesis.

\section{References}

Allen, A. W., Donaldson, G., Sniffen, R. C., and Goodale, F. (1954). Primary malignant lymphoma of the gastrointestinal tract. Ann. Surg., 140, 428-438.

Austed, W. I., Cornes, J. S., Gough, K. R., McCarthy, C. F., and Read, A. E. (1967). Steatorrhea and malignant lymphoma. The relationship of malignant tumours of lymphoid tissue and celiac disease. Amer. J. dig. Dis., 12, 475-490.

Ehrlich, A. N., Stalder, G., Geller, W., and Sherlock, P. (1968). Gastrointestinal manifestations of malignant lymphoma. Gastroenterology, 54, 1115-1121.

Eidelman, S., Parkins, R. A., and Rubin, C. E. (1966). Abdominal lymphoma presenting as malabsorption. Medicine (Baltimore), 45, 111-137.

Jackson, H., Jr., and Parker, F., Jr. (1944). Hodgkin's disease. II. Pathology. New Engl. J. Med., 231, 35-44.

Jinich, H., Rojas, E., Webb, J. A., and Kelsey, J. R. (1968). Lymphoma presenting as malabsorption. Gastroenterology, 54, 421-425.

Kent, T. H. (1964). Malabsorption syndrome with malignant lymphoma. Arch. Path., 78, 97-103.

Marcuse, P. M., and Stout, A. P. (1950). Primary lymphosarcoma of the small intestine. Analysis of 13 cases and review of the literature. Cancer (Philad.), 3, 459-474.

Ramot, B., Shahin, N., and Bubis, J. J. (1965). Malabsorption syndrome in lymphoma of small intestine. A study of 13 cases. Israal J. med. Sci., 1, 221-226.

Sacks, M. I., and Seijffers, M. J. (1968). Malabsorption syndrome and watery diarrhea in a 21-year-old man. Israel J. med. Sci., 4, 164-174.

Sleisenger, M. H., Almy, T. P., and Barr, D. P. (1953). The sprue syndrome secondary to lymphoma of the small bowel. Amer. J. Med., 15, 666-674. 